\title{
Phytoparasitic Nematodes Associated with Different Cultivars of Grape Grown in Two Types of Soil in Egypt.
}

\author{
Mohamed M.M.M. ${ }^{*}$, Korayem A.M. *, Montasser S. A. ${ }^{* *}$, Saeid Ananay A. M. ** \\ and D.M.D. Al-Baghdady** \\ * Plant Pathology Department (Nematology) National Research Centre -Dokki,Egypt \\ ${ }^{* *}$ Zoology and Nematology,Depart. Fact. Agric. Al-Azhar, University, Cairo,Egypt
}

\section{Abstract}

Survey was conducted in Giza, qualiabia and Behaira governorates of Egypt during 2010-2011 seasons, to study the occurrence and population density phytoparasitic nematodes associated with grapes (Vitis). A total number of 160 soil and root samples were collected from the rhizospher of six grape cultivars BezAlanza, Flame seedless, King Ruby, Romy Red, Superior and Thomoson seedless were collected by digging soils to a depth of $32-40 \mathrm{~cm}$ with stainless steel half tubes. The results indicated that the present of ten phytonematode genera, Criconemoides, Ditylenchus, Helicotylenchus, Hoplolaimus, Meloidogyne, Pratylenchus, Rotylenchulus, Tylenchorhynchus, Tylenchulus and Xiphinema. Frequency and population density of each nematode genera different according to grape cultivars and soil type. The root knot nematode (Meloidogyne) was prevalent nematode in all cultivars and localities it was present in $77.32 \%$ of total samples. Also root knot nematode (Meloidogyne) was frequent in ( $\mathrm{F} . \mathrm{O}=72.5 \%)$ than in clay soil $(16.77 \%)$, while the citrus nematode (Tylenchulus) was more frequent in clay soil (66.71) than in sandy soil $(0.67 \%)$.

Key words: Plant parasitic nematodes, frequency, grapevine, Egypt.

\section{Introduction}

Plant parasitic nematodes associated with grapes have been studied by many investigators in different areas of the world. Aphelenchus, Criconema, Criconemella, Criconemoides, Ditylenchus, Dolichodorus, Helicotylenchus, Hemicriconemoides, Hoplolaimus, Longidorus, Meloidogyne, Paratylenchus, Pratylenchus, Rotylenchulus, Rotylenchus, Scutellonema, Tylenchorhynchus, Tylenchulus and Xiphinema genera were recorded in association with grape soil and roots (Raski, et al., 1956 \& 1973; Otiefa \& Tarjan, 1965; McElory, 1972; Corio, et al., 1991 \& 1992; Lamberti, 1991; Vadivelu et al., 1992; Khan, et al., 1993; Liskova, et al., 1993; Roca \& Bravo, 1993; El-Maleh \& Edongali, 1995; Rubiano, et al., 1995; Malan, et al., 1997; Bello et al., 2002; Díez, et al., 2002; Escuer, et al., 2002; Hoschitz, 2002; Shin, 2005; Téliz, et al.,2007; Castillo, et al., 2009; Aballay, 2012 and Smith, 2012).

Allen (1952) reported that grapes injured by both Meloidogyne and Pratylenchus in California. 
Lamberti, et al. (1996) reported the occurrence of six species of Xiphinema on grape and other cultivated plants in Egypt. Feil et al. (1997) indicated that the root-knot nematode species were the most widespread and predominant species infecting grapevines in many different areas of the world.

In intensive survey studies carried out in different grape fields, the parasitic nematode genera, Criconemoides, Helicotylenchus, Hoplolaimus, Meloidogyne, Pratylenchus, Rotylenchulus, Tylenchorhynchus, Tylenchulus, and Xiphinema were found infesting vine fields with different frequencies of occurrence and population densities according to soil and/or host type. M. incognita was the prevalent root-knot species in all surveyed localities and cultivars in Egypt (Kesba, 1999).

Bello, et al. (2002) reported that, for the most part, Mediterranean agro systems are represented by potato, vegetables, citrus and fruit trees and vineyards. The main nematological problems in order of their economical importance were: root-knot (Meloidogyne incognita and M. javanica), cyst (Globodera pallida and G. rostochiensis), virus vector (Longidorus, Paratrichodorus, Trichodorus and Xiphinema), endoparasitic (Pratylenchus goodeyi), citrus (Tylenchulus semipenetrans) and ectoparasitic nematodes (Criconematidae, Hoplolaimidae and Tylenchidae).

Díez, et al. (2002) found that, plant-parasitic nematode problems were analyzed in the region of Castillay Leon, northwestern Iberian Peninsula. Nematode groups, from these problems: virus vector nematodes, among which Xiphinema index stands out, of interest in vineyards) and ectoparasitic nematodes, where Macroposthonia xenoplax stands out for causing chlorosis in grape.

Also, plant-parasitic nematode problems on grape in the region of Murcia in the southeastern Iberian Peninsula were analyzed. The nematode groups, from these problems: i) the root-knot nematodes, $M$. arenaria, $M$. incognita and $M$. javanica, which affect horticultural crops and fruit trees; ii) virus vector nematodes, among which Xiphinema index, of interest in vineyards, stands out; iii) the citrus nematode, Tylenchulus semipenetrans, found in citrus orchards and vineyards; and iv) ectoparasitic nematodes, among which Macroposthonia xenoplax stands out for causing necrosis (Escuer et al., 2002).

In Australian vineyards are being carried out within a 3 year research project. The predominant nematode genera, which were regularly detected and identified in infested as well as in un infested root samples, were Aphelenchus sp., Aphelenchoides sp. and Helicotylenchus sp. Plant-parasitic nematodes from eight families and free-living nematodes from 14 families were identified from soil samples. Prospects for the investigations in 2002 are presented (Hoschitz, 2002).

In Western Australia Shin, (2005) recorded that Meloidogyne, Xiphinema and Pratylenchus spp. were wide spread in Swan Valley and Margaret River vineyards. 
These nematode species were different in their behavior and damage that caused to grapevines but Meloidogyne spp. is the most difficult species to control because most of the time it remains in the root.

Mokbel, et al., (2006) found that in El-Behera Governorate (Egypt) the genera Criconema, Hemicriconemoides, Hemicycliophora, Hoplolaimus, Paratylenchus, Pratylenchoides, Scutellonema, Tetylenchus and Xiphinema were common in grape soil samples with $0.1-2.7 \%$ frequency of occurrence.

Incidence and nematode population densities of plant-parasitic nematodes were determined in 64 samples of soil and grapevine roots collected from commercial vineyards in southern Spain between October 2003 and May 2005. The most important plant-parasitic nematodes detected, in order of decreasing frequency of total soil infestation and root infection (percentage of samples), were Mesocriconema xenoplax (34.4\%), Meloidogyne incognita (26.6\%), Meloidogyne javanica (14.1\%), Xiphinema index (12.5\%), Xiphinema italiae (10.9\%), Pratylenchus vulnus (6.3\%), and Meloidogyne arenaria (1.6\%) (Téliz, et al., 2007).

Aballay, et al. (2012) reported that four nematode genera were highly pathogenic to the root system of Vitis in Chile. They indicated that the most frequent genera occurring in large population were Xiphinema index, $X$. americanum sensu lato, Meloidogyne spp., Mesocriconema xenoplax and Tylenchulus semipenetruns. Also, they mentioned that species of Xiphinema were present in $71 \%$ of the sampled area.

Castillo, et al. (2009) recorded that Meloidogyne hispanica was first found in Seville Province, southern Spain, infecting rootstocks of Prunus spp. Its distribution has been confirmed worldwide on different agricultural crops. Thus, M. hispanica has been reported to be infecting grapevines in South Africa and Australia; however, this is the first report of $M$. hispanica infecting grapevines in Europe. Data suggest that $M$. hispanica may pose a threat for vineyard production in southern Spain since M. hispanica was found in 52.63 and $47.36 \%$ of soil and root samples, respectively, from 19 fields in 'Condado de Huelva', with nematode population densities ranging from 2.4 to 129.6 eggs and J2s per $100 \mathrm{~cm}$ of soil and 1 to 1,797 eggs and J2s per gram of fresh roots.

In Chilean vineyards, Aballay, (2012) identified several of plant-parasitic nematodes species are associated with vineyards, the most important being the ectoparasite Xiphinema index and the endoparasite Meloidogyne ethiopica.

A survey study for identification and distribution of root-knot nematodes infected and parasitized grapevine plantations in Alexandria and El Behera Governorates revealed the presence of three species e.g. Meloidogyne arenaria, $M$. incognita and $M$. javanica. The root-knot nematode, $M$. incognita was the most common and presented in all the collected samples followed by $M$. javanica and $M$. arenaria (Mokbel et al., 2013). 


\section{Materials and Methods}

\section{Sampling Procedure:}

A total number of 160 soil and root samples from the rhizosphere of six grapevine cultivars, Bez Alanza, Flame Seedless, King Ruby, Romy Red, Sperior, and Thompson Seedless were collected from Giza, Qualubiya and Behaira governorates of Egypt.

Soil and root samples were collected by digging the soil to a depth of 30-35 $\mathrm{cm}$ with stainless steel half-tubes, kept at ambient shade temperature before nematode extraction. The collected samples were brought to the laboratory in polyethylene bags for enumeration and isolation of plant parasitic nematodes.

\section{Nematode Extraction and Numeration:}

Each soil sample was carefully mixed, and an aliquot of 250 gram was processed for nematode extraction according to methods described by Christie and Perry (1951). About 300-400 ml of water were added to the soil in a plastic pan and the mixture was agitated by fingers. After few seconds the suspension was poured onto a 60 mesh-sieve and passing suspension was collected in another clean plastic pan. Materials caught on the 60 mesh-sieve were discarded, while the collected suspension was then poured onto a 350 mesh-sieve. Materials remain on the sieve were thoroughly washed by a gently streamed of water into a $200 \mathrm{ml}$ beaker. The resulting suspension containing nematodes was then transferred to a Baerman-pan fitted with soft tissue paper for separation of active nematode from fine soil particles. After 48 hours nematode- water suspension was collected and concentrated to $20 \mathrm{ml}$ in a vial by using a 350 mesh-sieve. Aliquots of $1 \mathrm{ml}$ each of nematode suspension were pipette off, placed in a Hawksley counting slide and examined under a stereomicroscope. Nematode counts and identification to generic level were based on morphology of adult according to the description of Goodey (1963) and Mai and Lyon (1975).

\section{Results and Discussion}

Population density and frequency of occurrence of plant parasitic nematode genera associated with six viticultivars are presented in Table (1). Nematode genera associated with the surveyed grapevine cultivars were found to be variable according to the host cultivar. Data revealed the presence of 10 nematode genera i.e Criconemoides, Ditylenchus, Helicotylenchus, Hoplolaimus, Meloidogyne, Pratylenchus, Rotylenchulus, Tylenchorhynchus, Tylenchulus and Xiphinema.

In all grape cultivars, based on the total average of nematode frequencies of occurrence Meloidogyne were present at high frequencies in $77.32 \%$ of the samples. Followed by Xiphinema (45.24\%), Tylenchorhynchus (12.67\%), Rotylenchulus (12.63\%), and Helicotylenchus (12.32\%). Ditylenchus, Hoplolaimus, Pratylenchus and Tylenchulus occurred less frequently in 2.65, 3.44, 6.89 and 7.18 $\%$ 
Table (1): Population density and frequency of occurrence of plant parasitic nematode genera associated with six cultivars of grapevine

\begin{tabular}{|c|c|c|c|c|c|c|c|c|c|c|c|c|c|c|}
\hline \multirow[b]{3}{*}{ Nematode genera } & \multirow{2}{*}{\multicolumn{2}{|c|}{$\frac{\text { Bez Alanza }}{(6)}$}} & \multirow{2}{*}{\multicolumn{2}{|c|}{$\begin{array}{c}\begin{array}{c}\text { Flame } \\
\text { Seedless }\end{array} \\
(29)\end{array}$}} & \multirow{2}{*}{\multicolumn{2}{|c|}{$\frac{\text { King Ruby }}{\text { (1) }}$}} & \multirow{2}{*}{\multicolumn{2}{|c|}{$\frac{\text { Romy Red }}{(1)}$}} & \multirow{2}{*}{\multicolumn{2}{|c|}{$\begin{array}{c}\text { Superior } \\
(93)\end{array}$}} & \multirow{2}{*}{\multicolumn{2}{|c|}{$\begin{array}{c}\text { Thompson } \\
\text { Seedless } \\
(29)\end{array}$}} & \multirow{2}{*}{\multicolumn{2}{|c|}{ Total }} \\
\hline & & & & & & & & & & & & & & \\
\hline & P.D & F.O\% & P.D & F.O\% & P.D & F.O\% & P.D & F.O\% & P.D & F.O\% & P.D & F.O\% & P.D & F.O\% \\
\hline Criconemoides & - & - & 264 & 6.89 & - & - & - & - & 350 & 6.45 & 55 & 3.44 & 223 & 5.59 \\
\hline Ditylenchus & - & - & 130 & 3.44 & - & - & - & - & 130 & 1.07 & 93 & 3.44 & 118 & 2.65 \\
\hline Helicotylenchus & 80 & 33.33 & 90 & 3.44 & - & - & - & - & 871 & 2.15 & 270 & 10.34 & 328 & 12.32 \\
\hline Hoplolaimus & - & - & - & - & - & - & - & - & - & - & 93 & 3.44 & 93 & 3.44 \\
\hline Meloidogyne & 193 & 83.33 & 149 & 48.27 & - & - & 136 & 100 & 90 & 68.81 & 434 & 86.20 & 200 & 77.32 \\
\hline Pratylenchus & - & - & - & - & - & - & - & - & - & - & 73 & 6.89 & 73 & 6.89 \\
\hline Rotylenchulus & - & - & 126 & 13.79 & - & - & - & - & 67 & 17.20 & 192 & 6.89 & 128 & 12.63 \\
\hline Tylenchorhynchus & 90 & 16.66 & 348 & 17.24 & - & - & - & - & 210 & 6.45 & 368 & 10.34 & 254 & 12.67 \\
\hline Tylenchulus & - & - & 388 & 13.79 & - & - & - & - & 280 & 4.30 & 242 & 3.44 & 303 & 7.18 \\
\hline Xiphinema & 83 & 50.00 & 154 & 31.03 & 21 & 100 & - & - & 280 & 27.95 & 89 & 17.24 & 125 & 45.24 \\
\hline
\end{tabular}

P.D. = Population density of genus in $250 \mathrm{~g}$ soil.

F.O. = Frequency of occurrence.

Values with parentheses represent number of samples. 
These results are closely agree with those reported by Otifa and Tarjan, (1965), Moussa, et al. (1977) Taylor and Sassar, (1978), Hassan, (1985), Khan, et al., (1993), Rubiano, et al, (1995), Afia (1997), Kesba, (1999), Mokbel, et al., (2013).

\section{Population density and frequency of occurrence of plant parasitic nematode} genera on grapevine as influenced with soil types:

Plant parasitic nematode infecting grapevine are affected by soil types. Data in table (2) indicated that nematode genera greatly varied in their population densities and frequencies of occurrences according to soil types. Data indicated that Meloidogyne was more frequent in sandy soil $(72.29 \%)$ followed by Xiphinema $(29.05 \%)$ compared to their frequent in clay soil $(16.66 \%$ and $8.33 \%)$ respectively, Tylenchus and Tylenchulus were more frequent in clay soil25.01,16.7\%,6.3\%, $66.6 \%, 66.6 \%$ and $66.7 \%$ ) compared with their frequent in sandy soil, $4.1 \%$, $0.67 \%, 4.7 \%, 9.5 \%, 4.7 \%$ and $0.67 \%$, respctvely. Also it was observed that Criconemoides had highest nematode population in sandy soil (314), while highest population density was 1700 for Helicotylenchus in the clay soil. Hoplolaiums and Pratylenchus were found only in grapevine grown in sandy soil with relatively low population densities and frequencies of occurrences. Similar results under many plant hosts were obtained by several authors (Endo, 1959; Kinloch \& Sprenkel, 1994; Cadet \&Thioulouse, 1998 and Kesba, 1999) Phap, et al. (2009).

Table (2): Population density and frequency of occurrence of plant parasitic nematode genera associated with grapevine as influenced by two different soil types.

\begin{tabular}{lrrcc}
\hline \multirow{2}{*}{ Nematode genera } & \multicolumn{2}{c}{ Sandy soil (148) } & \multicolumn{2}{c}{ Clay soil (12) } \\
\cline { 2 - 5 } & P.D & F.O \% & P.D & F.0 \% \\
\hline Criconemoides & 314 & 4.05 & 267 & 25 \\
Ditylenchus & 93 & 0.67 & 130 & 16.66 \\
Helicotylenchus & 73 & 4.72 & 1700 & 8.33 \\
Hoplolaimus & 93 & 0.67 & - & - \\
Meloidogyne & 178 & 72.29 & 348 & 16.66 \\
Pratylenchus & 73 & 1.35 & - & - \\
Rotylenchulus & 62 & 9.45 & 135 & 66.66 \\
Tylenchorhynchus & 155 & 4.72 & 276 & 66.66 \\
Tylenchulus & 242 & 0.67 & 334 & 66.66 \\
Xiphinema & 85 & 29.05 & 136 & 8.33 \\
\hline P.D. = Population density in 250 soil. & \multicolumn{3}{c}{} \\
F.O. = Frequency of occurrence. & \multicolumn{3}{c}{} \\
Values with parentheses represent number of samples. & & & & \\
& & & &
\end{tabular}




\section{References}

Aballay E.; Persson P. and Martenssan A. (2012). Plant parasitc nematodes in Chilean vineyards. Nematropica, 39: 85-97.

Afia A.J.B. (1997). Host preference and biotype detection of citrus nematode, Tylenchulus semipenetrans in Egypt. Ph. D. Thesis, Fac. Agric., Cairo Univ.,110 pp.

Allen M. W. (1952). Observations on the genus Meloidogyne Geoldi, 1887. Proc. Helminth. Soc. Wash. 19 (1): 44-51.

Bello A.; Arias M.; Escuer M.; López-Pérez J. A.; García-Álvarez A.; LópezCepero J.; Acosta I. and Sanz R. (2002). Integrated and ecological nematode management in Canary Island crops. J. Nematol. 4(2): 300.

Cadet P. and Hioulouse J. (1998). Identification of soil factors that relate to plant parasitic nematode communities on tomato and yam in the French West Indies. Applied Soil Ecology 8: 35-49.

Castillo P.; Gutiérrez-Gutiérrez C.; Palomares-Rius J. E.; Cantalapiedra Navarrete C. and Landa, B. B. (2009). First report of root-knot nematode Meloidogyne hispanica infecting grapevines in Southern Spain. Plant Dis., 93, 1353.

Christie J. R. and Perry V. G. (1951). Removing nematodes from soil. Proceedings of Helminthological Society of Washington. 17: 106 - 108.

Corio M. L, Borgo M. and Agostinelli A.(1992). The Trichoderidae (Nematoda) in the vineyards of the province of Verona. Nematologia Medierranea, 20 (2): 245-250.

Corio M.L.; Escuer M.; Agostinelli A. and Bello A. (1991). Criconematidea in vineyards of Conegliano and Vadobbiadene, in the province of Treviso, Italy. Nematologia Mediterranea, 19 (1):113-119.

Díez M. A.; Escuer, M. and Bello A. (2002). Nematode problems in Castillay Leon (Spain), a continental Mediterranean climate. J. Nematol. 4(2): 264. (Abstr., 399).

El-Maleh A. and Edongali Z. (1995). Plant parasitic nematodes associated with grapevine in Libya.Pakistan J. Nematol.,13 (2): 77-81.

Endo B.Y. (1959). Responses of root-lesion nematodes, Pratylenchus brachyurus and $P$. zeae, to various plants and soil types. Phytopathol. 49:417-421.

Escuer M.; Cano A. and Bello A. (2002). Nematode problems in the region of Murcia (Spain), a Mediterranean Model. J. of Nematol. 4(2): 265. 
Feil H.; Westerdahl B.B.; Smith RJ. and Verdegaal P. (1997). Effects of seasonal and site factors on Xiphinema population in two California vineyards. J. Nematol., 29 (4): 491-500.

Goodey J.B. (1963). Soil and fresh water nematodes. Methuem and Co., LTD. London, New York, Jhon Wiley and Sons, Inc. 544 pp.

Hassan M.W.A. (1985). Physiological and histological studies on some citrus and grape plants and their relationship to nematodes.

Hoschitz M. (2002). First year interim results of investigations on the nematode fauna in the pedobiocoenosis of grape phylloxera (Dactylophora vitifolii) infested vines (Vitis vinifera) in selected Austrian vine production areas. J. of Nematol. 4(2): 266. (Abstr., 406).

Kesba H. H. (1999). Ecological and pathological studies on some plant parasitic nematodes infecting grape, Vitis vinifera L. M.Sc. Thesis, Fac. of Agric., Cairo Univ., Egypt. 114 pp.

Khan F.A.; Erinle, I.D. and Chindo P.S. (1993). Survey of plant parasitic nematodes associated in 4 northern states of Nigeria and observation on grapevine fanleaf virus. Journal of African Zoology, 107 (5):505-510.

Kinloch R. A. and Sprenkel R. K. (1994). Plant-Parasitic nematodes associated with cotton in Florida. J. Nematol., 26: 749-752.

Lamberti F.;Agostinelli A. and Radicci V. (1996). Longidorid nematodes from northern Egypt. Nematologia Mediterranea, 24: 307-339.

Lamberti F.(1991). Parasitic nematodes of vines and their control. Vigne vini, 18(11):43-46.

Liskova M.; Sabova M.; Valoka B. and Lamberti F. (1993). Occurrence of Xiphinema diversicaudatum (Nematoda) in the Slovak Republic. Nematologia Mediterranea, 21 (1):107-109.

Mai W.F. and Lyon H.H. (1975). Pictorial key to genera of plant parasitic nematodes. Cornell Univ. press, Ithaca, New York, 219 pp.

Malan A.P.; Swart, A.; Meyer A.J. and Heyns J. (1997). Description of two new Xiphinema species (Nematoda: Dorylaimida) from South Africa. African Plant Protection, 3 (1): 39-46.

McElory F.J.X. (1972). Nematodes of tree fruits and small fruits. Pp. 335-376 in Webster. (ed).

Mokbel A.A.; Ibrahim I.K.A.; EL-Saedy M.A.M. and Hammad S.E. (2013). Plant parasitic nematodes associated with some fruit trees and vegetable crops in Northern Egypt. Egypt. J. Phytopathol., 34 (2): 43-51. 
Moussa N. A.; McGrath J. J.; Cravalho E. G. and Asimacopoulos P. J. (1977). Kinetics of thermal injury in cells. J. Biomech. Eng. 99:155-159.

Oteifa B.A. and Tarjan A.C. (1965). Potentially important plant parasitic nematodes present in established orchards of newly reclaimed sandy areas of The United Arab Rep ublic. Plant Dis.Reptr.,49:596- 597.

Phap Q. T.; De La Pena E.; Nguyen C. N.; Nguyen H. X. and Moens M. (2009). Plant-parasitic nematodes associated with coffee in Vietnam. Russian J. Nematol., 17 (1): $73-82$.

Raski D. J.; Sher S.A. and Jensen F.N. (1956). New HOST RECORDS of the citrus nematode in California. Plant Dis. Rep., 40:1047-1048

Raski D. J.; Hart W.H. and Kasimatis A.N. (1973). Nematodes and their control in vienyards. Calif.Agric.Ext.Serv.Circ.533 (Revised) 20pp.

Roca F. and Bravo M.A.(1993). The occurrence of Xiphinema sphaerocephalum Lamberti et al.and $X$. hispanum Lamberti et al. (Nematoda Longidoridae) in Portugal with descriptions of $X$. lanceolatum sp.n. and $X$. lapidosum sp. n. Fundamental and Applied Nematol., 16 (5): 455-465.

Rubiano J.A.; Agudelo F.V. and De-Agudelo F.V. (1995). Identification and parasitism of grape Vitis spp. Fitopatologia Colombiana, 19 (2): 27-35.

Rubiano J.A.; Agudelo F.V. and De-Agudelo F.V. (1995). Identification and parasitism of grape Vitis spp. Fitopatologia Colombiana, 19 (2): 27-35.

Shin H. S. (2005). Effect of irrigation systems, partial root zone drying irrigation and regulated deficit, on plant parasitic populations in grapevine. M.Sc. Thesis, Fac. of Natural and Agricultural Sci., Univ. of Western Australia.

Smith B. (2012). Which little bugger is that? Identifying root-knot nematodes in Australia. In B. Smith and P. Clingeleffer (Eds) " In Crush 2012 the grape and wine sci. symposium" session 2- paper 5. Waite Campus, Adelaide.

Taylor A. L. and Sasser J.N. (1978). Biology, identification and control of the rootknot nematodes (Meloidogyne species).111, Dept. PI. Pathol. North Carolina St.Univ. Graphics, Releigh.

Téliz D.; Landa B. B.; Rapoport H. F.; Pérez Camacho F.; Jiménez-Díaz R. M. and Castillo P.( 2007). Plant-parasitic nematodes infecting grapevine in southern Spain and susceptible reaction to root-knot nematodes of rootstocks reported as moderately resistant. Plant Dis. 91:1147-1154.

Vadivelu S.; Balasubramaniam P.;Chinniah C. and Rajendran G. (1992). Association of nematodes with grapevines in Tamil Nadu. Current Nematol.,3 (2): 159-166. 


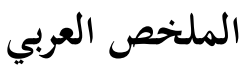

أنواع النيماتودا نباتية التغذية والمصاحبة على بعض أصناف العنب المنزرعة في أنواع تربة مختلفة في مصر

معوض محمد محمد محمد*؛ سيد عبد العزيز منتصر **؛ أحمد محمد كريم*؛ عبدالمنعم السعيد

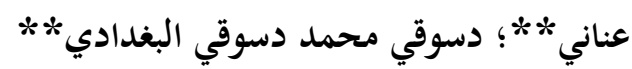

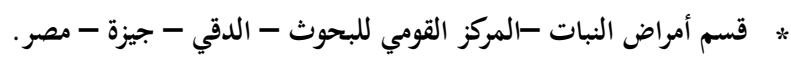

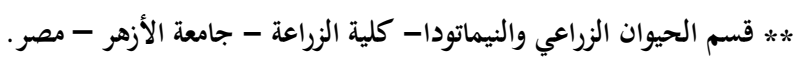
أجريت هذه الدراسة في ثلاث محافظات وهي: الجيزة، القليوبية، والبحيرة، لحصر أنواع النيماتودا

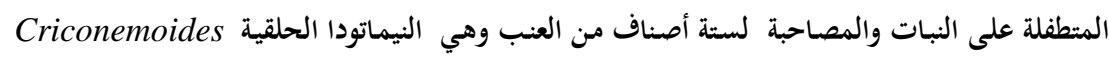

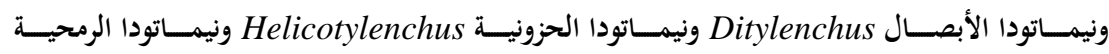

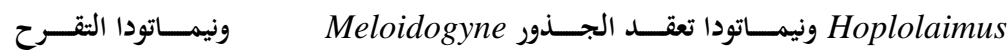

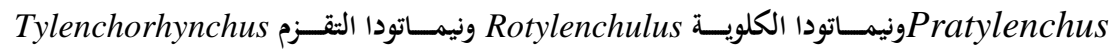
ونيماتودا الموالح Tylenchulus ونيماتودا الخنجرية Xiphinema وقد تم جمع (160) عينة من تربة

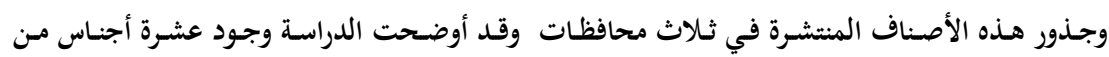

Criconemoides, Ditylenchus, Helicotylenchus, النيماتودا نباتية التغذية وهي Hoplolaimus, Meloidogyne, Pratylenchus, Rotylenchulus, Tylenchorhynchus, Tylenchulus and Xiphinema

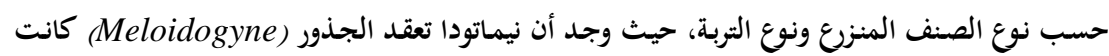
أكثر ظهورًا في كل الأصناف، حيث ظهرت في نسبة 77.3 من كل العينات التي جمعت من كل الأصناف.

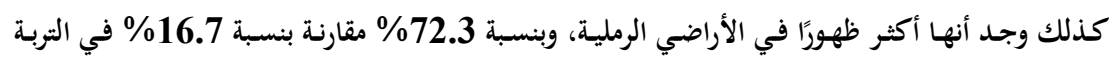

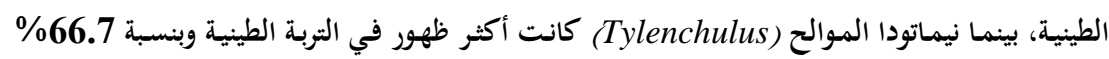

$$
\text { مقارنة بنسبة } 0.76 \text { في الأراضي الرملية. }
$$

